MATEC Web of Conferences 53, 01062 (2016)

DOI: $10.1051 /$ matecconf/20165301062

(C) Owned by the authors, published by EDP Sciences, 2016

\title{
Review on Upper Limb Continuous Passive Motion Devices
}

\author{
Francesco Ragazzo, a \\ ${ }^{1}$ Polibrixia, R\&D Department, 25123 Brescia, Italy
}

\begin{abstract}
The paper is devoted to a survey on the state of the art of elements and parts for the upper limb rehabilitation. As a matter of fact, the use of technological, and specifically of robotic, devices is entering in the habits of clinical approaches, due to their ability to work efficiently and to be able to obtain, at least, the same rehabilitation results of manual therapy. At the same time, the therapists can change his/her role in rehabilitation activity from a physical contribution to an intellectual/motivational one.
\end{abstract}

\section{Introduction}

As shown in literature, mobilization is effective in rehabilitation to improve the motor function and to reduce pain $[1,2]$. These results can be obtained for different pathologies: stroke [3], cerebral palsy [4], osteoarthritis [5, 6], etc. Under these hypotheses, Salter, who proposed the continuous passive motion (CPM), derived this concept on the basis of a series of experimental investigations and well thought-out rationale. Salter and Field [7] showed in 1960 that immobilization of a rabbit knee joint under continuous compression, provided by either a compression device or forced position, resulted in pressure necrosis of the cartilage. In 1965, Salter et al. reported deleterious effects of immobilization on the articular cartilage of rabbit knee joints and the resultant lesion that they termed "obliterative degeneration of articular cartilage". Salter believed that "The relative place of rest and of motion is considerably less controversial on the basis of experimental investigation than on the basis of clinical empiricism". He reasoned that because immobilization is obviously unhealthy for joints, and if intermittent movement is healthier for both normal and injured joints, then perhaps continuous motion would be even better. Because of the fatigability of skeletal muscle, and because a patient could not be expected to move his or her own joint constantly, he concluded that for motion to be continuous it would also have to be passive.

\section{State of the art}

CPM devices are mechatronics systems [8], or, in the most complex solutions, a robotic device [9-14] able to implement automatically a CPM rehabilitation. A large number of devices and methods for CPM rehabilitation is well known in literature. The aim of this paper is to show the most interesting devices currently used for the rehabilitation of wrist and hand. Some of these devices are designed to perform both a coordinate movement and different exercises. Many of these do not realize a complete

\footnotetext{
${ }^{\mathrm{a}}$ Corresponding author : f.ragazzo86@gmail.com
} 
movement, for example, only flexor-extensor or abdo-adduction. Two list of CPM devices are shown (Table 1-2), respectively, for the wrist and for the hand rehabilitation.

Table 1. List of devices for CPM wrist rehabilitation. E.D. Electrical driver.

\begin{tabular}{|l|l|l|l|l|l|}
\hline Device name & Ref. & Year & Exercises & ROM & Other \\
\hline $\begin{array}{l}\text { Hand Mentor - } \\
\text { Kinetic } \\
\text { muscles, inc. }\end{array}$ & {$[15]$} & 2008 & $\begin{array}{l}\text { Flex and ext wrist and } \\
\text { fingers. }\end{array}$ & $\begin{array}{l}\text { Flexor limit 90 } \\
\text { extensor limit } \\
90^{\circ} .\end{array}$ & $\begin{array}{l}\text { Control security } \\
\text { system, rotation } \\
\text { reverse. P. D. }\end{array}$ \\
\hline $\begin{array}{l}\text { Patent US } \\
5,458,560\end{array}$ & {$[16]$} & 1995 & Flex and ext wrist & - & E.D. \\
\hline $\begin{array}{l}\text { Patent US } \\
7,618,381\end{array}$ & {$[17]$} & 2009 & $\begin{array}{l}\text { Flex-ext abdo-addu of } \\
\text { wrist }\end{array}$ & - & E.D. \\
\hline
\end{tabular}

Table 2. List of CPM devices for hand rehabilitation. E.D. Electrical driver, V.F. visual feedback. CPM continuous passive motion, CAM continuous active motion.

\begin{tabular}{|c|c|c|c|c|c|}
\hline Device name & Ref. & Year & Exercises & ROM & Other \\
\hline Gloreha & {$[18]$} & 2011 & Flex and ext finger. & $\begin{array}{l}\text { Compete of flex } \\
\text { or ext exercise }\end{array}$ & $\begin{array}{lr}\text { Moves } & \text { fingers } \\
\text { smoothly, } & \text { both } \\
\text { individually } & \text { and } \\
\text { simultaneously. V.F. }\end{array}$ \\
\hline $\begin{array}{l}\text { Tyromotion } \\
\text { Amadeo }\end{array}$ & [19] & 2011 & $\begin{array}{l}\text { Flex and ext fingers } \\
\text { (Active and passive } \\
\text { exercises). }\end{array}$ & $\begin{array}{l}\text { Compete of flex } \\
\text { or ext exercise }\end{array}$ & $\begin{array}{l}\text { V.F., individual and } \\
\text { contemporary } \\
\text { exercises, } \\
\text { calibration. }\end{array}$ \\
\hline Artromot-F & {$[20]$} & 2008 & Flex and ext finger. & $\begin{array}{l}\text { Compete of flex } \\
\text { or ext exercise }\end{array}$ & $\begin{array}{ll}\text { LCD display } & \text { for } \\
\text { monitoring, } & \\
\text { microcomputer } & \text { for } \\
\text { control system. } & \end{array}$ \\
\hline Patent & {$[21]$} & 1987 & Flex and ext finger & $\begin{array}{l}\text { Compete of flex } \\
\text { or ext exercise }\end{array}$ & $\begin{array}{l}\text { Security system } \\
\text { control. E.D. }\end{array}$ \\
\hline Patent & {$[22]$} & 1990 & Flex and ext finger & $\begin{array}{l}\text { Compete of flex } \\
\text { or ext exercise }\end{array}$ & $\begin{array}{l}\text { Spiral motion, Security } \\
\text { control system E.D. }\end{array}$ \\
\hline Patent & {$[23]$} & 2010 & $\begin{array}{l}\text { Flex ext finger CPM } \\
\text { CAM }\end{array}$ & $90^{\circ}$ Flex-Ext & $\begin{array}{ll}\text { Security } & \text { control } \\
\text { system, E.D } & \end{array}$ \\
\hline
\end{tabular}

Different actuator systems are shown in literature [24-26] and are classified with different criteria; one of the most common classifications is based on the used technology: piezoelectric devices [27, 28], electric motors [29, 30], shape memory actuators [31-37], etc. The most commonly used devices are electric ones that represent also the most common choice in rehabilitation devices.

\section{Electrical driver's rehabilitation}

When a designer starts a project, the first specification is on electrical drivers. There is two possible solution, on the patient body or separate from body. For the first one, the electrical drivers have to be light and small, because the size can impede the movement. For the second solution, the driver's size is not important but transmission is essential. On the market there are two principal families of electrical drivers: rotary motors and linear motors. 
Rotary motors. The use brushless motors is more frequent in biomechanics [29] because they are efficient with intermittent movement. Usually the electrical devices are used with a speed reducer [30]. Nowadays these devices are cheap. Another kind of rotary motors are DC drivers. These drivers are usually employed for their easy control. Asynchronous motors are used for repetitive movements because changing the speed is difficult and expensive. The final results are shown in Table 3.

Table 3. Difference between rotary motors.

\begin{tabular}{|l|l|l|l|l|l|}
\hline Type & Max torque & $\begin{array}{l}\text { Movement } \\
\text { type }\end{array}$ & $\begin{array}{l}\text { Driver } \\
\text { electronic }\end{array}$ & Cost & Maintenance \\
\hline Brushless & $\begin{array}{l}\text { Average-high } \\
\text { torque }\end{array}$ & $\begin{array}{l}\text { Not } \\
\text { periodic } \\
\text { movements }\end{array}$ & $\begin{array}{l}\text { Necessary and } \\
\text { complex } \\
\text { electrical circuit }\end{array}$ & High & Sometimes \\
\hline DC & Low torque & $\begin{array}{l}\text { Not } \\
\text { periodic } \\
\text { movements }\end{array}$ & $\begin{array}{l}\text { Not necessary } \\
\text { and easy }\end{array}$ & Low Frequent \\
\hline Asynchronous & High torque & $\begin{array}{l}\text { Periodic } \\
\text { movements }\end{array}$ & $\begin{array}{l}\text { Necessary for } \\
\text { speed regulation }\end{array}$ & Low & Rarely \\
\hline
\end{tabular}

Linear motors. The relative position of the armature and stator of a linear motor is controlled using the output of two optional transducers in phase quadrature from an optical grid disposed along the length of the stator. This device is very expensive and little used.

\section{Mechanical transmission}

The movement's generation is based on electrical drivers with high-speed. Transmission is used for reducing and changing movement of end-effectors. In sequence, after the motor there is a speedreducer. The most used are divided into main classes: ordinary reducer, epicyclical reducer, Harmonic-Drive reducer and RV-A reducer. The first is less used for low efficiency. The most used system is epicyclic reducer because it is cheap and it has a good efficiency. The Harmonic-Drive has a high ratio but it does not allow the retrograde movement. The final results are in Table 4.

Table 4. Difference between reducers.

\begin{tabular}{|l|l|l|l|l|}
\hline Type & Ratio & Efficiency & $\begin{array}{l}\text { Retrograde } \\
\text { motion }\end{array}$ & Cost \\
\hline Ordinary reduc. & $1 / 10 \mathrm{max}$ & Very low & Yes & Low \\
\hline Epicyclic reduc. & $1 / 10 \div 1 / 200$ & Sufficient & Yes & Intermediate \\
\hline Harmonic-Drive & $1 / 50 \div 1 / 400$ & High & No & High \\
\hline RV-A reduc. & $1 / 50 \div 1 / 400$ & Very high & No & Very High \\
\hline
\end{tabular}

After the reducer usually there is the transmission's movement. For this problem there are a lot of solution: belt, machanisms system, cogwheel, flexible shafts [38] and chain. Interesting solutions are characterized by a fluid media as power transmission system [39-41]. Flexible shafts can divide the part where there are the electrical motor and the limb of patient. 


\section{Future developments}

The main problem is that the science is not secure of methods and exercises for a correct rehabilitation. This uncertainty does not allow a singular way for the designing rehabilitation devices. The first work is defining correct exercises and methods, for specifics pathologies with the collaboration of medical staff. Once they will be defined, research could start the mechatronic design. Nowadays we are still looking for these suggestions from medical staff to implement a proper solution for rehabilitation designing a complete device, both for the wrist and for the hand. Two important characteristics are:

-the coordinating exercise, that is when the patient use more than one degree of freedom in an exercise, i.e. to move the wrist in flexo-extension and abdo-adduction together.

-the visual feedback of exercise for the patient is very important in rehabilitation, because, if the patient watches the virtual movement on the monitor, it is possible to activate intact neuronal systems that provide direct stimulation to motor areas affected by brain lesions.

An interesting demanded function for these systems is the possibility of realizing a specific motion profile [42-46], whereas the common state of the art is based on the possibility of assigning an actuation motion, thus a proper system must realize a kinematic inversion [47-49] to transform a finger motion in an actuator motion and, then, properly optimize [50-53] the motion profile of the actuator to realize the desired finger motion, with an adequate control system [52-54].

\section{Conclusions}

In conclusion of this paper, on the market there is not a complete device for the wrist and hand rehabilitation with coordinated movements, that could be used for a large range of pathologies from neuronal to orthopedic disease. The rehabilitative research is very important, because only they are able to suggest the exact way for realizing instruments and methods for rehabilitation.

\section{References}

[1] J. H. Villafane, G. B. Silva, M. D. Bishop, and J. Fernandez-Carnero, Archives of physical medicine and rehabilitation, 93, 396-403, Mar 2012

[2] J. H. Villafane, G. B. Silva, S. A. Diaz-Parreno, and J. Fernandez-Carnero, Journal of manipulative and physiological therapeutics, 34, 547-56, Oct 2011

[3] A. Sundseth, B. Thommessen, and O. M. Ronning, Journal of stroke and cerebrovascular diseases : the official journal of National Stroke Association, May 132013

[4] D. P. Grogan, M. S. Lundy, and J. A. Ogden, Journal of pediatric orthopedics, 7, 338-40, May-Jun 1987

[5] J. H. Villafane, M. D. Bishop, C. Fernandez-de-Las-Penas, and D. Langford, Journal of physiotherapy, 59, 25-30, Mar 2013

[6] J. H. Villafane, J. A. Cleland, and C. Fernandez-de-Las-Penas, The Journal of orthopaedic and sports physical therapy, 43, 204-13, Apr 2013

[7] R. B. Salter and P. Field, The Journal of Bone \& Joint Surgery, 42, 31-90, 1960

[8] F. Aggogeri, A. Borboni, and R. Faglia, Applied Mechanics and Materials, 373-375, 130133,2013

[9] C. Amici, A. Borboni, and R. Faglia, Advances in Mechanical Engineering, 2010, 706023, 20102010

[10] C. Amici, A. Borboni, R. Faglia, D. Fausti, and P. L. Magnani, Proceedings of the IEEE/RSJ International Conference on Intelligent Robots and Systems, 2008, 735-740

[11] G. Taveggia, J. H. Villafañe, F. Vavassori, C. Lecchi, A. Borboni, and S. Negrini, Journal of Manipulative and Physiological Therapeutics, 37, 242-252, 2014 
[12] A. Borboni, R. Faglia, and M. Mor, ASME 2014 12th Biennial Conference on Engineering Systems Design and Analysis ESDA 2014, 1, 1-10, 2014

[13] C. Amici, A. Borboni, P. L. Magnani, and D. Pomi, Proceedings of EUCOMES 2008 - The 2nd European Conference on Mechanism Science, 2008, 487-493, 2009

[14] C. Amici, A. Borboni, P. L. Magnani, and D. Pomi, Proceedings of EUCOMES 2008 - The 2nd European Conference on Mechanism Science, 2008, 479-485, 2009

[15] L. Rosenstein, A. L. Ridgel, A. Thota, B. Samame, and J. L. Alberts, The American journal of occupational therapy : official publication of the American Occupational Therapy Association, 62, 28-35, Jan-Feb 2008

[16] R. T. Kaiser, R. Zambelli, G. Telepko, B. C. Kalustyan, and V. Ricci, "Continuous passive motion device for a wrist," U.S. Patent 5,458,560, Ottobre 1995, 1995

[17] H. I. Krebs, N. Hogan, D. Williams, and J. Celestino, "Wrist and upper extremity motion," U.S. Patent 7,618,381, Novembre 2009, 2009

[18] K. I. Ites, E. J. Anderson, M. L. Cahill, J. A. Kearney, E. C. Post, and L. S. Gilchrist, Journal of geriatric physical therapy, 34, 109-16, Jul-Sep 2011

[19] J. Stein, L. Bishop, G. Gillen, and R. Helbok, American journal of physical medicine \& rehabilitation / Association of Academic Physiatrists, 90, 887-94, Nov 2011

[20] M. Syrko and J. Jablecki, Chirurgia narzadow ruchu i ortopedia polska, 73, 257-8, Jul-Aug 2008

[21] J. B. Yates and L. M. Lubbers, "Hand exerciser," U.S. Patent 4,644,938, Febbraio 1987, 1987

[22] D. Shamir and M. W. Groves, "Continuous passive motion device for imparting a spiral motion to the digits of the hand," U.S. Patent 4,962,756, Ottobre 1990, 1990

[23] E. J. W. Park, B. J. Birch, C. E. Haslam, N. Dechev, and I. Heerah, "Continuous passive and active motion device and method for hand rehabilitation," U.S. Patent 12,539,565, Agosto 2009, 2009

[24] A. Borboni, D. De Santis, and R. Faglia, 10th Biennial Conference on Engineering Systems Design and Analysis ESDA2010, 2010, 99-106

[25] F. Aggogeri, A. Borboni, R. Faglia, A. Merlo, and S. De Cristofaro, Applied Mechanics and Materials, 336-338, 1170-1173, 20132013

[26] A. Borboni and D. De Santis, Meccanica, 49, 1327-1336, 2014

[27] A. Borboni, D. De Santis, and R. Faglia, Proceedings of 8th Biennial ASME Conference on Engineering Systems Design and Analysis, 2006

[28] A. Borboni and R. Faglia, Journal of Applied Mechanics, 80, 021003-021003, 2013

[29] H. R. Johnson, "Permanent Magnet Motor," U.S. Patent 4,151,431, Aprile 1979, 1979

[30] R. J. Tolmie Jr, "Integrated driver-encoder assembly for brushless motor," Patent US 4,988,905, Gennaio 1991, 1991

[31] A. Borboni, Aggogeri, F.; Faglia, R., International Journal of Advanced Robotic Systems, 10, $1-10,2013$

[32] K. K. Ahn and N. B. Kha, Mechatronics, 18, 141-152, Apr 2008

[33] A. Borboni, F. Aggogeri, N. Pellegrini, and R. Faglia, Advanced Materials Research, 590, 405-410, 2012

[34] A. Bhattacharyya, W. L. Ables, G. Kumara, and M. A. Qidwai, Smart Structures and Materials 2004 Active Materials Behavior and Mechanics, 2004, 118-127

[35] A. Borboni, R. Faglia, and M. Palpacelli, MESA 2014 - 10th IEEE/ASME International Conference on Mechatronic and Embedded Systems and Applications, 1, 1-7, 2014

[36] A. Borboni and R. Faglia, Procedia Engineering, 2014, 1378-1381

[37] M. Tiboni, A. Borboni, M. Mor, and D. Pomi, Proceedings of the Institution of Mechanical Engineers. Part I: Journal of Systems and Control Engineering, 225, 443-451, 2011

[38] B. Kovačič, R. Kamnik, Z. Kapović, Geodetski List, 63 (4), 315-327 (2009)

[39] B. Kovačič, R. Kamnik, A. Štrukelj, Promet - Traffic - Traffico, 22 (1), 15-22 (2010)

[40] V.V Okrepilov, Standarty i Kachestvo, 3, 94-96. (2003)

[41] V.V Okrepilov, Ivanova, G. Standarty i Kachestvo, 12, 62-68. (2004) 


\section{MATEC Web of Conferences}

[42] A. Borboni, F. Aggogeri, N. Pellegrini, and R. Faglia, Advanced Materials Research, 590, 399-404, 2012

[43] H. Li, M. D. Le, Z. M. Gong, and W. Lin, Ieee-Asme Transactions on Mechatronics, 14, 264269, Apr 2009

[44] K.-H. Rew and K.-S. Kim, Ieee Transactions on Industrial Electronics, 57, 2499-2506, Jul 2010

[45] A. Borboni and M. Lancini, Journal of Vibration and Acoustics, Transactions of the ASME, 137, 1-9, 2015

[46] A. Borboni, R. Bussola, R. Faglia, P. L. Magnani, and A. Menegolo, Journal of Mechanical Design, Transactions of the ASME, 130, 0823011-0823016, 2008

[47] A. Borboni, IEEE International Conference on Fuzzy Systems, 2001, 336-339

[48] D. N. Nenchev, Proceedings of the IEEE International Conference on Robotics and Automation, 1994, 2698-2703

[49] A. Ramdane-Cherif, B. Daachi, A. Benallegue, N. Levy, and I. Ieee, Proceedings of the Ieee/Rsj International Conference on Intelligent Robots and Systems, 2002, 1904-1909

[50] M. Antonini, A. Borboni, R. Bussola, and R. Faglia, Proceedings of 8th Biennial ASME Conference on Engineering Systems Design and Analysis, 95122, 20102006

[51] M. Antonini, A. Borboni, R. Bussola, and R. Faglia, Proceedings of 8th Biennial ASME Conference on Engineering Systems Design and Analysis, 95123, 20102006

[54] Y. Shi, J. Huang, and B. Yu, Ieee Transactions on Industrial Electronics, 60, 5864-5874, Dec 2013

[55] F. Aggogeri, A. Borboni, A. Merlo, and N. Pellegrini, Advanced Materials Research, 590, 252-257, 2012

[56] F. Xu, L. Shi, and Y. Li, Ieee Transactions on Power Electronics, 28, 5665-5672, Dec 2013 